\title{
Ellipsis
}

Volume 43

Article 9

2016

\section{Painted into a Corner}

Michelle Lepori

University of New Orleans

Follow this and additional works at: https://scholarworks.uno.edu/ellipsis

\section{Recommended Citation}

Lepori, Michelle (2016) "Painted into a Corner," Ellipsis: Vol. 43 , Article 9.

DOI: https://doi.org/10.46428/ejail.43.09

Available at: https://scholarworks.uno.edu/ellipsis/vol43/iss1/9

This Poetry is brought to you for free and open access by the Department of English and Foreign Languages at ScholarWorks@UNO. It has been accepted for inclusion in Ellipsis by an authorized editor of ScholarWorks@UNO.

For more information, please contact scholarworks@uno.edu. 


\title{
Painted into a Corner
}

\author{
Michelle Lepori
}

I.

Have your emptiness

And let it hold you at night

Too close for comfort;

Let it sweat on your skin

Underneath a fleece blanket

And steal the t-shirt covered pillow.

In the middle of a bad dream

Have it call out for help,

But there is no one there;

It is emptiness.

Go back to sleep. No one

Will be saved by this idea-

It is a meaningless echo

Off a wordless canyon of

Crumbled carved rock.

II.

I should have seen the fence being born and the pink ribbon in your painting, not as a sign of love for me but of remembrance to the day we sat under the shaded oak tree and I vented too much and listened too little.

Now I see that you remembered the pink plastic ribbon hugging the present perennial and painted it flailing in the winda clear signal for me to help, to help, to help! I did not see your feelings as separate from me.

Now there is trash underwater, a deep turquoise blue, and the sky is all fenced in except one spot where perhaps you have not finished painting. Perhaps you will paint that in too and then there will be no more reaching you. 